\title{
The G-Protein-coupled Receptor Kinases $\beta$ ARK1 and $\beta$ ARK2 Are Widely Distributed at Synapses in Rat Brain
}

\author{
Jeffrey L. Arriza, ${ }^{1}$ Ted M. Dawson, ${ }^{2}$ Richard B. Simerly, ${ }^{3}$ Lee J. Martin, ${ }^{2}$ Marc G. Caron, ${ }^{1}$ Solomon H. Snyder, ${ }^{2}$ \\ and Robert J. Lefkowitz ${ }^{1}$ \\ 'Departments of Medicine, Cell Biology, and Biochemistry, Howard Hughes Medical Institute, Duke University Medical \\ Center, Durham, North Carolina 27710, 2Departments of Neuroscience, Neurology, Pathology, Pharmacology and \\ Molecular Sciences, and Psychiatry, The Johns Hopkins School of Medicine, Baltimore, Maryland 21205, and ${ }^{3}$ Division of \\ Neuroscience, Oregon Regional Primate Research Center, Beaverton, Oregon, 97006
}

\begin{abstract}
The $\beta$-adrenergic receptor kinase ( $\beta$ ARK) phosphorylates the agonist-occupied $\beta$-adrenergic receptor to promote rapid receptor uncoupling from $G_{\mathrm{s}}$, thereby attenuating adenylyl cyclase activity. $\beta$ ARK-mediated receptor desensitization may reflect a general molecular mechanism operative on many G-protein-coupled receptor systems and, particularly, synaptic neurotransmitter receptors. Two distinct cDNAs encoding $\beta$ ARK isozymes were isolated from rat brain and sequenced. The regional and cellular distributions of these two gene products, termed $\beta$ ARK 1 and $\beta$ ARK2, were determined in brain by in situ hybridization and by immunohistochemistry at the light and electron microscopic levels. The $\beta$ ARK isozymes were found to be expressed primarily in neurons distributed throughout the CNS. Ultrastructurally, $\beta$ ARK 1 and BARK2 immunoreactivities were present both in association with postsynaptic densities and, presynaptically, with axon terminals. The $\beta$ ARK isozymes have a regional and subcellular distribution consistent with a general role in the desensitization of synaptic receptors.
\end{abstract}

Synaptic signal transduction, and the molecular events that constitute this process, are fundamental to the function of neuronal circuits. Of particular interest are mechanisms by which the strength of synaptic transmission may be either enhanced or diminished. Regulation of neurotransmitter signal transduction at the level of the synaptic receptor is a potentially important mechanism of synaptic plasticity. A substantial body of evidence now suggests that phosphorylation events regulate the functions of both G-protein-coupled receptors and ligand-gated ion channel receptors (reviewed by Sibley et al., 1987; Klein et al., 1989; Huganir and Greengard, 1990). The functional consequences of G-protein-coupled receptor phosphorylation have been extensively studied using the $\beta_{2}$-adrenergic receptor $\left(\beta_{2} \mathrm{AR}\right)$

\footnotetext{
Received Mar. 12, 1992; revised May 22, 1992: accepted May 27, 1992.

We thank S. El Mestikawy, M. Hnatowich, R. Fremeau, J. Pitcher, H. Attramadal, C. Aoki, and C. Stone for advice and discussion. This work was supported by the Howard Hughes Medical Institute by IJ.S. Public Health Service Grants NS-26723 to R.B.S., AG-05146 and NS-20471 to L.J.M., DA-00266 and MH18501 to S.H.S., HL-16037 to R.J.L., and by Research Scientist Award DA-00074 and a gift from Bristol-Myers-Squibb to S.H.S. T.M.D is a Pfizer Postdoctoral Fellow and is supported by grants from the American Academy of Neurology, the French Foundation for Alzheimer's Research, and the Dana Foundation. R.B.S. is supported by a research award from the Theodore and Vada Stanley Foundation.

Correspondence should be addressed to Robert J. Lefkowitz, M.D., Box 3821, Duke University Medical Center, Durham, NC 27710.

Copyright (C) 1992 Society for Neuroscience $0270-6474 / 92 / 124045-11 \$ 05.00 / 0$
}

as a model system (reviewed by Benovic et al., 1988; Hausdorff et al., 1990). In the $\beta_{2} \mathrm{AR}$ system, agonist binding initiates processes that, concurrent with $\mathrm{G}_{\mathrm{s}}$-mediated stimulation of adenylyl cyclase, serve to phosphorylate rapidly and thereby desensitize these receptors. The desensitization of the $\beta_{2} \mathrm{AR}$ by phosphorylation is reversible (Sibley et al., 1986), presumably through the activity of protein phosphatases. Thus, at synapses, the desensitization of G-protein-coupled receptors by phosphorylation may lead, at least transiently, to attenuated neurotransmission despite persistent stimulation.

Distinct pathways for the phosphorylation and desensitization of the $\beta_{2} \mathrm{AR}$ are mediated by the cAMP-dependent protein kinase (PKA), and by the $\beta$-adrenergic receptor kinase or $\beta$ ARK (Hausdorff et al., 1989). PKA is activated by the second messenger product of $\beta_{2} \mathrm{AR}$ stimulation (cAMP) to phosphorylate sites on the receptor that directly inhibit receptor- $\mathrm{G}_{\mathrm{s}}$ coupling and thereby limit further stimulation of adenylyl cyclase. However, PKA is a general regulator of cell physiology and the consequences of PKA activation can include desensitization or potentiation of heterologous receptor systems (Benovic et al., 1988; Huganir and Greengard, 1990; Greengard et al., 1991; Wang et al., 1991). In contrast, this laboratory has purified and characterized $\beta$ ARK, a serine/threonine kinase activity that specifically phosphorylates the hormone-activated form of the $\beta_{2} \mathrm{AR}$ (Benovic et al., 1987a). $\beta$ ARK-mediated receptor desensitization is, therefore, homologous in the sense that only those receptors binding agonist are potential substrates. Moreover, $\beta$ ARK phosphorylation of the $\beta_{2} \mathrm{AR}$ itself causes only minimal inhibition of receptor $-G_{s}$ coupling (Benovic et al., 1987b). Instead, $\beta$ ARK phosphorylation promotes the association of a cofactor, $\beta$-arrestin, that is required to effect receptor desensitization (Lohse et al., 1990). $\beta$ ARK phosphorylation of the $\beta_{2} \mathrm{AR}$, therefore, represents a distinct pathway for homologous receptor desensitization.

$\beta$ ARK-mediated desensitization may be a general mechanism that regulates the responses of many G-protein-coupled receptors. In addition to the $\beta_{2} \mathrm{AR}$, purified $\beta \mathrm{ARK}$ has been shown to phosphorylate the $\alpha_{2 \mathrm{~A}}$-adrenergic receptor (Benovic et al., $1987 \mathrm{c}$ ), the $\mathrm{M}_{2}$ muscarinic ACh receptor (Kwatra et al., 1989), and even the photoreceptor rhodopsin (Benovic et al., 1986) in a stimulus-dependent manner. Although a full assessment of the range of potential $\beta A R K$ substrates has been limited by the availability of purified receptors, these data suggest that stimulus-dependent phosphorylation by $\beta \mathrm{ARK}$ is a common feature 
of the G-protein-coupled receptor family. Furthermore, the requirement of receptor agonist-occupation for $\beta$ ARK phosphorylation leads to the expectation that this desensitization pathway would be functionally important when receptors are exposed to high agonist concentrations, as occurs at the synapse (Hausdorff et al., 1990). Accordingly, desensitization of neurotransmitter receptors via $\beta$ ARK might represent a general process regulating neurotransmission.

A significant step toward evaluating the role of $\beta$ ARK-mediated desensitization in the nervous system would be to determine if the distribution of $\beta \mathrm{ARK}$ expression is consistent with its proposed general and synaptic functions. Recent developments from molecular cloning have provided the means to examine the expression of $\beta \mathrm{ARK}$ as well as an additional complexity: two closely related, yet distinct, cDNA sequences encoding " $\beta$ ARK" have been cloned from bovine brain (Benovic et al., 1989, 1991). Since both gene products exhibit $\beta$ ARKlike characteristics (i.e., agonist-dependent phosphorylation of the $\beta_{2} \mathrm{AR}$ ), these kinases are referred to as $\beta \mathrm{ARK}$ isozymes, with the first gene isolated termed $\beta A R K 1$ and the second $\beta A R K 2$. The pattern of expression for each $\beta \mathrm{ARK}$ isozyme may reflect its function. For example, each $\beta$ ARK isozyme could be associated with a subset of $G$-protein-coupled receptors; if so, this might be indicated by differences in the distributions of $\beta$ ARK 1 and $\beta A R K 2$. Moreover, the subcellular localization of these kinases in proximity to synaptic receptors would provide a factual basis for a postulated function of $\beta A R K$-mediated desensitization in neurotransmission. To address these issues, we have isolated the rat homolog of the two bovine $\beta$ ARK genes and developed specific nucleic acid and immunological probes to determine the distributions of $\beta$ ARK isozyme expression in the CNS.

\section{Materials and Methods}

$c D N A$ cloning and plasmid constructs. The rat $\beta \mathrm{ARK} 1$ and $\beta \mathrm{ARK} 2$ cDNAs were isolated from a whole rat brain $\lambda$ gt $11 \mathrm{cDNA}$ library using portions of the previously described bovine $\beta A R K 1$ and $\beta A R K 2$ sequences as probes (Benovic et al., 1989, 1991). The $\beta$ ARKI probe was a 717 base pair (bp) SacI fragment from p $\beta$ ARK-3A (Benovic et al., 1989) radiolabeled with ${ }^{32} \mathrm{P}-\mathrm{dCTP}$ by nick translation, whereas the $\beta A R K 2$ probe was a 1.3 kilobase $(\mathrm{kb})$ HindIII fragment of $\mathrm{p} \beta$ ARK2 (Benovic et al., 1991). Hybridization conditions consisted of $50 \%$ formamide, $5 \times$ saline-sodium citrate (SSC), $1 \times$ Denhardt's solution, $0.1 \%$ SDS, salmon sperm at $100 \mu \mathrm{g} / \mathrm{ml}$, and probe $\left(10^{6} \mathrm{cpm} / \mathrm{ml}\right)$ at $42^{\circ} \mathrm{C}$. Final wash conditions were $0.1 \times \mathrm{SSC}, 0.1 \% \mathrm{SDS}$ at $65^{\circ} \mathrm{C}$. Purified phage clones were subcloned into pBluescript II (Stratagene) for sequencing by the dideoxynucleotide chain termination method of Sanger et al. (1977) using synthetic oligonucleotide primers, double-stranded DNA template, and Sequenase 2.0 (U.S. Biochemical). Plasmid pr $\beta$ ARK 1 contains a rat BARK 1 cDNA isolated from a single phage clone and is $2676 \mathrm{bp}$ in length. The rat $\beta$ ARK 2 cDNA sequences in plasmid pr $\beta$ ARK 2 are a 2464 bp composite derived from three overlapping clones. Due to its low abundance, the large size of the $\beta A R K 2$ mRNA $(>7.5 \mathrm{~kb})$, and the use of an oligo(dT)-primed library, $\beta A R K 2$ sequences were poorly represented and fragmented.

For expression in COS-7 cells, rat $\beta$ ARK1 and $\beta A R K 2$ coding sequences were inserted into pCMV5 (Andersson et al., 1989). The $\beta A R K 1$ cDNA was excised from pr $\beta$ ARK 1 using BamHI and HindIII polylinker-derived restriction sites and inserted into BglII- and HindIII-cut pCMV 5 to form plasmid pCMV- $\beta$ ARK 1 , the rat $\beta$ ARK 1 expression vector. Similarly, the $\beta$ ARK 2 cDNA was excised with restriction enzymes HindIII and BamHI and inserted into HindIII- and BamHI-cut pCMV5 to form the rat $\beta$ ARK2 expression vector PCMV- $\beta$ ARK2.

Probes used for in situ hybridization were previously utilized in RNase protection assays (Benovic et al., 1991). The $\beta$ ARK1 transcription vector pGEM- $\beta$ ARK 1 contains a $407 \mathrm{bp} \mathrm{Sacl/Xbal}$ fragment from $\beta A R K 1$ cDNA inserted into the SacI/Xbal polylinker sites of pGEM-
4Z (Promega). This plasmid was linearized at the polylinker HindIII site for transcription with SP6 polymerase to produce antisense cRNA probe. pGEM- $\beta$ ARK2 contains a $421 \mathrm{bp}$ DraI/PstI fragment of $p \beta A R K 2$ cDNA inserted into the SmaI/PstI polylinker sites of pGEM-4Z. This plasmid was linearized at the polylinker EcoRI site for transcription with T7 polymerase to generate antisense cRNA probe.

Fusion proteins expressed in Escherichia coli were generated using pGEX-2T (Pharmacia) constructs in which C-terminal coding sequences of rat $\beta$ ARK 1 and $\beta$ ARK 2 were ligated in-frame with sequences encoding glutathione-S-transferase (GST). Using the polymerase chain reaction technique, sequences encoding amino acid sequences 467-689 of rat $\beta$ ARK 1 or residues $467-688$ of rat $\beta$ ARK2 were synthesized with flanking BamHI and EcoRI restriction sites for subcloning into BamHIand EcoRI-cut pGEX-2T, forming plasmids pGEX- $\beta 1 \mathrm{CT}$ or pGEX$\beta 2 \mathrm{CT}$.

Transfections, COS-7 cell extract preparation, and $\beta_{2} A R$ phosphorylation. Functional assays for the rat $\beta \mathrm{ARK} 1$ and $\beta \mathrm{ARK} 2$ gene products were performed by transfecting COS-7 cells with expression plasmid, harvesting cells for cytosolic extracts, and assaying these extracts for agonist-dependent phosphorylation of purified, lipid-reconstituted hamster $\beta_{2}$ AR. Subconfluent COS-7 cells maintained in Dulbecco's modified Eagle's medium with $10 \%$ fetal calf serum were transfected by the DEAE-dextran method (Lopeta et al., 1984) with $30 \mu \mathrm{g}$ of either pCMV- $\beta$ ARK 1 or pCMV- $\beta$ ARK2 DNA per $150 \mathrm{~mm}$ plate. Control extracts were prepared from cells transfected with pCMV5. Cells were harvested $2 \mathrm{~d}$ after transfection by scraping in $2 \mathrm{ml}$ of $50 \mathrm{mM}$ Tris, $\mathrm{pH}$ $7.5,5 \mathrm{mM}$ EDTA, $0.1 \mathrm{mM}$ phenylmethylsulfonyl fluoride, $5 \mu \mathrm{g} / \mathrm{ml}$ pepstatin, and $10 \mu \mathrm{g} / \mathrm{ml}$ benzamidine, homogenized with a Brinkmann tissue disruptor, and centrifuged at $300,000 \times g$ for $20 \mathrm{~min}$ at $4^{\circ} \mathrm{C}$. Protein concentrations were determined using the method of Bradford (1976). To assay kinase activity in cell extracts, the $\beta_{2}$ AR was purified from hamster lung (Benovic et al., 1984) and reconstituted into phospholipid vesicles as described previously (Cerione et al., 1983). Phosphorylation reactions $(35 \mu \mathrm{l})$ contained $20 \mathrm{mM}$ Tris, $\mathrm{pH} 7.5,2 \mathrm{mM}$ EDTA, $6 \mathrm{mM} \mathrm{MgCl}_{2}, 0.7 \mathrm{mM}$ dithiothreitol, $0.7 \mathrm{mM}$ ascorbic acid, 20 $\mu \mathrm{M}$ cAMP-dependent protein kinase inhibitor (Sigma), $100 \mu \mathrm{M}$ ATP, $0.3 \mu \mathrm{Ci}$ of $\gamma-{ }^{32} \mathrm{P}-\mathrm{ATP}$ (New England Nuclear; $6000 \mathrm{Ci} / \mathrm{mmol}$ ), $1.0 \mathrm{pmol}$ of reconstituted receptor, and $4 \mu \mathrm{g}$ of COS-7 cell extract protein. (-)Isoproterenol was added to a final concentration of $100 \mu \mathrm{M}$. After incubation $\left(30 \mathrm{~min}\right.$ at $\left.30^{\circ} \mathrm{C}\right)$, reactions were terminated by addition of 0.5 $\mathrm{ml}$ of $0.1 \mathrm{M} \mathrm{NaPO}_{4} / 10 \mathrm{mM}$ EDTA, centrifuged at $300,000 \times \mathrm{g}$ for 15 min at $4^{\circ} \mathrm{C}$ to pellet vesicles, and resuspended in $2 \times$ SDS loading buffer prior to resolution on $10 \%$ SDS polyacrylamide gels under reducing conditions (Laemmli, 1970), fixation, and autoradiography on Kodak XAR film.

In situ hybridization histochemistry. Tissue sections were processed for in situ hybridization as described previously (Simerly and Young, 1991). Briefly, anesthetized adult male Sprague-Dawley rats were perfused with $4 \%$ paraformaldehyde and frozen sections of the brains were collected and processed for in situ hybridization using ${ }^{35}$ S-UTP-labeled asymmetric RNA probes transcribed from pGEM- $\beta$ ARK1 and pGEM$\beta A R K 2$. Radioactive cRNAs were diluted to an activity of $1.5 \times 10^{7}$ $\mathrm{dpm} / \mathrm{ml}$ with hybridization buffer containing $50 \%$ formamide, $0.25 \mathrm{M}$ $\mathrm{NaCl}, 1 \times$ Denhardt's solution, and $10 \%$ dextran sulfate. Hybridizations were carried out for $20-22 \mathrm{hr}$ at $60^{\circ} \mathrm{C}$. After hybridization, slides were washed in $2 \times \mathrm{SSC}$, subjected to RNase digestion $(20 \mu \mathrm{g} / \mathrm{ml}, 30 \mathrm{~min}$ at $37^{\circ} \mathrm{C}$ ), and progressively rinsed in decreasing concentrations of SSC to a final stringency of $0.1 \times \mathrm{SSC}$ at $65^{\circ} \mathrm{C}$. Sections were exposed to $\mathrm{Du}$ Pont Cronex film for $8 \mathrm{~d}$. Sections were subsequently dipped in NTB2 liquid emulsion, developed in Kodak D-19 developer, and counterstained with thionin through the emulsion. The probes used here for in situ hybridization were selective for either $\beta$ ARK 1 or $\beta A R K 2$ mRNAs in RNase protection assays (Benovic et al., 1991), and a variety of experimental controls indicated that these cRNA probes were selective for $\beta$ ARK isozyme mRNAs in these histochemical analyses. Control experiments included hybridization using probes not complementary to $\beta$ ARK mRNA, or hybridization following RNase treatment. In addition, analyses of the thermal stability of probe hybrids werc performed as described previously (Simerly et al., 1990), and the results indicate that each of the probes used in this study hybridizes to single, fully homogeneous target mRNAs (Lewis et al., 1985).

Antibody preparation and Western blot analyses. $\beta$ ARK1- or $\beta$ ARK2specific polyclonal antibodies were raised by immunization of New Zealand White rabbits with GST fusion proteins. Fusion proteins were purified using glutathione-Sepharose 4B (Pharmacia) from E. coli (DH5 $\alpha$ ) 


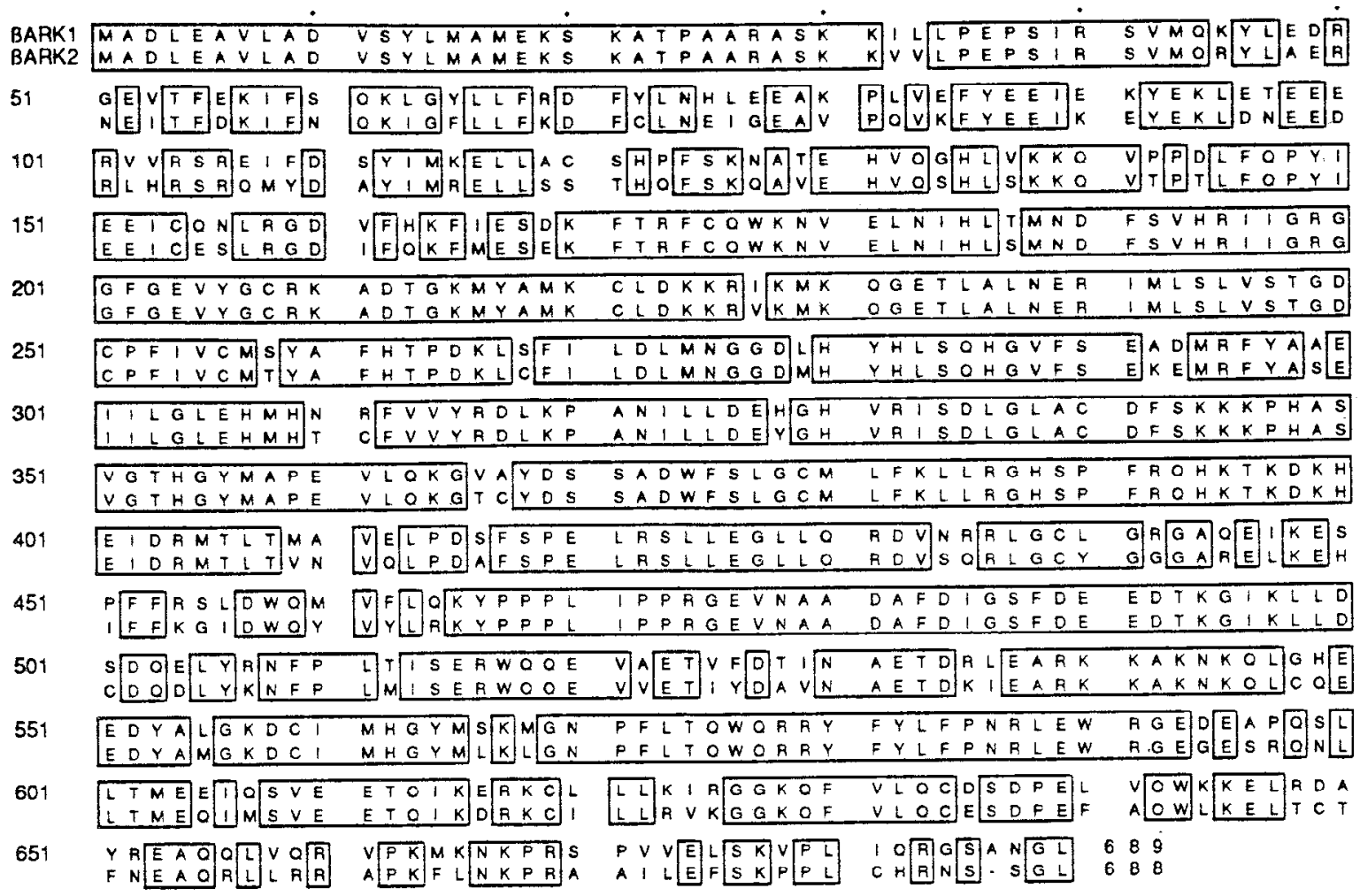

Figure 1. Amino acid sequences of rat $\beta$ ARK1 and rat $\beta$ ARK2. The 689 residues of $\beta$ ARK1 and 688 residues of $\beta$ ARK2 deduced from the nucleotide sequences of rat brain cDNAs are shown using the one-letter amino acid code. Regions of sequence identity are enclosed within boxes. A single gap introduced into the $\beta$ ARK2 sequence for this alignment is represented by a dash. The nucleotide sequences of rat $\beta$ ARK1 and $\beta$ ARK2 cDNAs can be accessed under accession numbers M87854 ( $\beta$-ARK1, $2683 \mathrm{bp}$ ) and M87855 ( $\beta$-ARK2, 2464 bp) from the GenBank database.

transformed with pGEX- $\beta 1 \mathrm{CT}$ or pGEX- $\beta 2 \mathrm{CT}$ and induced with isopropyl-1-thio- $\beta$-D-galactopyranoside as described previously (Smith and Johnson, 1988). Rabbits were inoculated and then boosted every 4 weeks with $300-500 \mu \mathrm{g}$ of purified fusion protein in Freund's adjuvant (GIBCO). Sera were immunoaffinity purified on antigen columns in which 1-3 mg of purified $\beta$ ARK 1 or $\beta$ ARK2 fusion protein (dialyzed against $0.1 \mathrm{M}$ HEPES, $\mathrm{pH} 7.5$ ) was bound to $1 \mathrm{ml}$ of Affi-Gel 15 support (Bio-Rad) according to the manufacturer's instructions. Several methods were employed to obtain antibodies specific for either the $\beta$ ARK1 or $\beta$ ARK2 gene products. Sera against $\beta$ ARK1 fusion protein were bound to a $\beta A R K 1$ antigen column, washed, and sequentially eluted with low $\mathrm{pH}(0.1 \mathrm{M}$ glycine, $\mathrm{pH} 2.5)$, high $\mathrm{pH}(0.1 \mathrm{M}$ triethylamine, $\mathrm{pH} 11$ ), and $3.5 \mathrm{M} \mathrm{MgCl}_{2}$. Each fraction was $\mathrm{pH}$ neutralized, stabilized with BSA ( $1 \mathrm{mg} / \mathrm{ml}$ final), dialyzed against PBS, and assayed for specificity by immunoblotting of transiently transfected COS-7 cell extracts. The $\mathrm{MgCl}_{2}$ eluate, with an IgG concentration estimated at $10 \mu \mathrm{g} / \mathrm{ml}$ by absorbance measured at $280 \mathrm{~nm}$, was found to be $\beta A R K 1$ specific. $\beta$ ARK2 sera were bound to a $\beta$ ARK2 antigen column and processed as described above, but all fractions were found to cross-react with $\beta$ ARK 1 . To remove cross-reacting antibodies, the low $\mathrm{pH}$ and high $\mathrm{pH}$ eluates were pooled and passed over a $\beta A R K 1$ antigen column. The unbound antibodies, with an estimated concentration of $500 \mu \mathrm{g} / \mathrm{ml}$, were specific for $\beta$ ARK2.

For immunoblot analysis, cytosolic extracts were prepared as described above and size fractionated ( $20 \mu \mathrm{g}$ per lane of COS-7 cell extract and $150 \mu \mathrm{g}$ per lane of tissue extract) on $10 \%$ SDS polyacrylamide gels, transferred to nitrocellulose, stained with Ponceau red, and blocked with 3\% BSA. Blots were developed using a goat anti-rabbit alkaline phosphatase kit (Bio-Rad) according to the manufacturer's protocol except for the use of $3 \%$ BSA instead of gelatin in all antibody buffers.

Immunohistochemistry. Adult male Sprague-Dawley rats were perfused with PBS followed by $4 \%$ freshly depolymerized paraformaldehyde in $0.1 \mathrm{M}$ phosphate buffer (PB). The brains were removed and postfixed for $2 \mathrm{hr}$ in 4\% paraformaldehyde in PB followed by cryoprotection in $20 \%(\mathrm{v} / \mathrm{v})$ glycerol in PB. Free-floating sections $(40 \mu \mathrm{m})$ were then cut on a sliding microtome (Reichert-Jung) and permeabilized for
30 min with $0.2 \%$ Triton $\mathrm{X}-100$ (TX-100) in Tris-buffered saline (TBS; $50 \mathrm{mM}$ Tris- $\mathrm{HCl}, \mathrm{pH} 7.2,1.5 \% \mathrm{NaCl}$ ) followed by a $1 \mathrm{hr}$ block in $4 \%$ normal goat serum (NGS), $0.1 \%$ TX-100 in TBS. The free-floating sections were then transferred to TBS containing $2 \%$ NGS, $0.1 \%$ TX100 , and affinity-purified antibodies to $\beta$ ARK1 (1:5 dilution) or $\beta$ ARK2 (1:500 dilution) and incubated overnight at $4^{\circ} \mathrm{C}$. The sections were stained with an avidin-biotin-peroxidase system (Vector Laboratories) with diaminobenzidine (DAB) as a chromogen. Blocking experiments were performed by preabsorbing the $\beta A R K 1$ or $\beta A R K 2$ antisera with $100 \mu \mathrm{g}$ of their respective purified fusion protein antigen.

For electron microscopic evaluation of $\beta$ ARK immunoreactivity, adult male and female Sprague-Dawley rats were perfused intra-aortically with cold PBS, followed by $4 \%$ paraformaldehyde, $0.1 \%$ glutaraldehyde, $15 \%$ saturated picric acid in PBS $(30 \mathrm{ml} / \mathrm{min}$ for $20 \mathrm{~min}$ ), or, alternatively, with cold PBS followed by $4 \%$ paraformaldehyde, $2.5 \%$ acrolein in PBS ( $30 \mathrm{ml} / \mathrm{min}$ for $20 \mathrm{~min})$. The brains were removed, blocked postfixed for $1 \mathrm{hr}$, and rinsed overnight in PBS at $4^{\circ} \mathrm{C}$. Coronal sections $(40 \mu \mathrm{m})$ were cut on a Vibratome, transferred to TBS, and treated for 10 min with $0.08 \%$ TX-100 in TBS or with a freeze-thaw procedure. Sections were preincubated for $1 \mathrm{hr}$ with $4 \%$ NGS diluted in TRS and incubated for $48 \mathrm{hr}$ at $4^{\circ} \mathrm{C}$ with affinity-purified antibodies at dilutions of $1: 10$ to $1: 500$ in 2\% NGS in TBS. Control sections were incubated with comparable amounts of rabbit IgG or with primary antiserum omitted. Following incubation, sections were rinsed for $30 \mathrm{~min}$ in TBS, incubated $1 \mathrm{hr}$ with goat anti-rabbit immunoglobulin (Cappel) diluted at 1:100, rinsed for $30 \mathrm{~min}$ in TBS, and incubated for $1 \mathrm{hr}$ with rabbit peroxidase-antiperoxidase (PAP) complex (Sternberger Monoclonals) diluted at 1:200. For additional controls, the secondary antibody and the PAP were omitted from the incubation solution. After the final incubation, sections were rinsed for $30 \mathrm{~min}$ in TBS and developed using a standard DAB reaction. After the disclosing reaction, samples $(\sim 2$ $\mathrm{mm}^{2}$ ) were taken from Vibratome sections, treated for $1 \mathrm{hr}$ with $2 \%$ osmium tetroxide, dehydrated, stained en bloc with uranyl acetate, and flat-embedded in resin. Plastic-embedded sections were mounted on an Araldite block and cut in semithin $(1 \mu \mathrm{m})$ and ultrathin (gold to silver interference color) sections for light and electron microscopy, respec- 


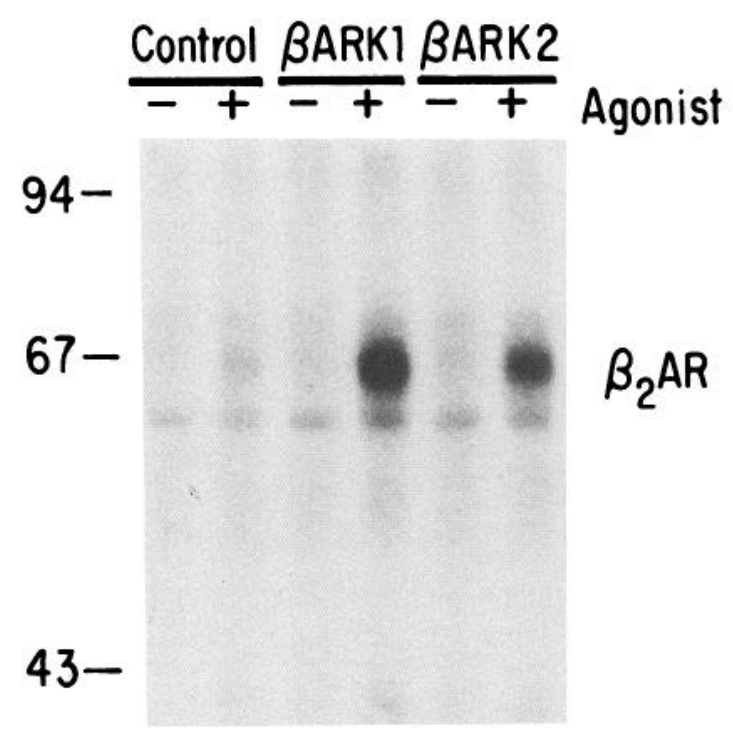

Figure 2. Agonist-dependent phosphorylation of the $\beta_{2} \mathrm{AR}$ by expressed $\beta A R K 1$ and $\beta$ ARK2. The kinase activities of the $\beta$ ARK isozymes on the $\beta_{2}$ AR were assayed in extracts from COS-7 cells transiently transfected with either the parental expression vector pCMV5 (Control), the rat $\beta$ ARK 1 cDNA expression construct $(\beta A R K 1)$, or the rat $\beta$ ARK2 cDNA expression construct $(\beta A R K 2)$. Extracts were incubated with purified, reconstituted hamster $\beta_{2} \mathrm{AR}$ in the presence of ${ }^{32} \mathrm{P}-\mathrm{ATP}$ and in the absence $(-)$ or presence $(+)$ of $(-)$ isoproterenol (Agonist). Products were size fractionated on $10 \%$ SDS-polyacrylamide gels under reducing conditions and the phosphorylated receptor visualized by autoradiography. The position of molecular weight standards (kilodaltons) are indicated.

tively. Ultrathin sections, with or without lead citrate staining, were viewed with a Hitachi-600, a Philips CM12, or a Joel 100 S electron microscope.

\section{Results}

\section{Structure and activity of two rat $\beta A R K$ gene products}

To isolate the rat homolog of the genes for bovine $\beta$ ARK1 and $\beta$ ARK2, portions of the bovine cDNAs (Benovic et al., 1989, 1991) were used to detect and purify their counterparts from a whole rat brain $\lambda \mathrm{gt} 11 \mathrm{cDNA}$ library. The nucleotide sequences of the cDNAs encoding rat $\beta$ ARK1 and $\beta$ ARK 2 were determined, and their predicted amino acid sequences are shown in Figure 1 . The rat $\beta$ ARK1 and $\beta$ ARK2 gene products are structurally very similar, with $\sim 81 \%$ amino acid identity and predicted molecular weights of $79.8 \mathrm{kDa}$ and $79.9 \mathrm{kDa}$, respectively. When compared with their bovine counterparts, $78.5 \%$ of the amino acids are conserved within all four sequences and only $10.5 \%$ of all amino acid positions are gene specific (i.e., $\beta$ ARK1 vs $\beta$ ARK2 differences conserved across species).

The functional activity of these two rat $\beta$ ARK gene products was assessed by their ability to phosphorylate purified, lipidreconstituted $\beta_{2} \mathrm{AR}$ in an agonist-dependent manner. Coding sequences were transiently expressed in COS-7 cells and cytosolic extracts prepared for use in an in vitro receptor phosphorylation assay. Extracts from $\beta$ ARK1- and $\beta$ ARK2-transfected cells, but not from control (i.e., vector-transfected) cells, phosphorylated the $\beta_{2} \mathrm{AR}$ in an agonist-dependent manner, demonstrating that both expressed proteins are functional (Fig. 2 ). However, the extent of phosphorylation observed with $\beta A R K 1$ extracts was reproducibly greater than that of $\beta$ ARK2 extracts. Similar results have been reported with the bovine $\beta$ ARK gene products (Benovic et al., 1991). When compared with bovine $\beta$ ARK 1 , bovine $\beta$ ARK2 was only $50 \%$ as active in phosphorylating the $\beta_{2} \mathrm{AR}$, whereas both $\beta \mathrm{ARK}$ isozymes had equivalent activity on a synthetic peptide substrate (Benovic et al., 1991).

\section{$\beta A R K 1$ and $\beta A R K 2 \mathrm{mRNAs}$ are expressed in widespread neuronal populations}

The regional distributions of $\beta$ ARK1 and $\beta$ ARK 2 mRNA expression in rat brain were determined using in situ hybridization histochemistry with radiolabeled cRNA probes. $\beta$ ARK1 and $\beta A R K 2$ mRNA-containing cells were widely distributed throughout each major subdivision of the CNS. As shown in Figure 3, $\beta$ ARK1 labeling was generally more intense than labeling with the $\beta$ ARK 2 probe under comparable conditions. In isocortex, labeling for $\beta$ ARK1 mRNA was more abundant and more uniformly distributed in the cortical layers than the labeling obtained with the probe for $\beta$ ARK2 mRNA, which was primarily localized to layers II, III, and VI. In the thalamus, the central median, paraventricular, and reticular nuclei exhibit moderate to high levels of $\beta$ ARK1 mRNA compared with $\beta$ ARK2 mRNA. In some regions, the relative levels of $\beta$ ARK1 and $\beta$ ARK2 mRNA were roughly equivalent. This was particularly apparent in the hippocampus, where intense labeling for $\beta A R K 1$ and $\beta$ ARK2 was observed over the pyramidal layer of CA1 and over the granular layer of dentate gyrus. Only a few cell groups, such as the tenia tecta, the islands of Calleja, and the compact part of the substantia nigra, were found to express significantly higher levels of $\beta$ ARK 2 mRNA relative to $\beta$ ARK 1 mRNA.

The expression of $\beta$ ARK 1 and $\beta$ ARK 2 mRNAs appeared to be largely neuronal. Cellular labeling (determined by the presence of dense clusters of silver grains over cells in emulsioncoated sections) was found over thionin-stained neurons, with very few silver grains over fiber tracts or over what appeared to be glial cells. On the other hand, diffuse labeling over mixed clusters of neurons and glia with the $\beta$ ARK 1 probe suggests that $\beta$ ARK1 mRNA may also be expressed at low levels in glia. Although the striatum generally displayed low overall hybridization signals (Fig. $3 A, B$ ), clearly labeled neurons were detected within the striatum in the emulsion-coated material. The extensive degree of labeling seen in many regions, such as the hippocampus, suggests that these two kinases may be expressed in the same neuron.

\section{Characterization of $\beta A R K$ isozymes by immunoblotting}

Antibodies specific for either $\beta$ ARK1 (anti- $\beta$ ARK1) or $\beta$ ARK2 (anti- $\beta$ ARK2) were produced and characterized by Western blot analysis (Fig. 4) prior to immunohistochemistry. Extracts prepared from COS-7 cells expressing either rat $\beta$ ARK1 or $\beta$ ARK2 were immunoblotted with either the anti- $\beta$ ARK1 or the anti$\beta$ ARK2 antibodies. Under these assay conditions (i.e., roughly equivalent amounts of both antigens present), antibody crossreactivity is very limited, with $\beta$ ARK1 but not $\beta$ ARK 2 protein being recognized by the anti- $\beta$ ARK 1 antibody, and vice versa (Fig. 4 , left panels). Whereas the cloned $\beta$ ARK genes have predicted molecular weights of $\sim 80 \mathrm{kDa}$, the expressed rat $\beta$ ARK1 cDNA product migrates with an apparent $M_{r}$ of $\sim 82 \mathrm{kDa}$. In contrast, the expressed $\beta$ ARK 2 cDNA product migrates at an $M_{r}$ of $\sim 77 \mathrm{kDa}$. Extracts from dissected brain regions exhibit immunoreactive $\beta$ ARK proteins with mobilities similar to those of the expressed cDNA products (Fig. 4, right panels). Consistent 


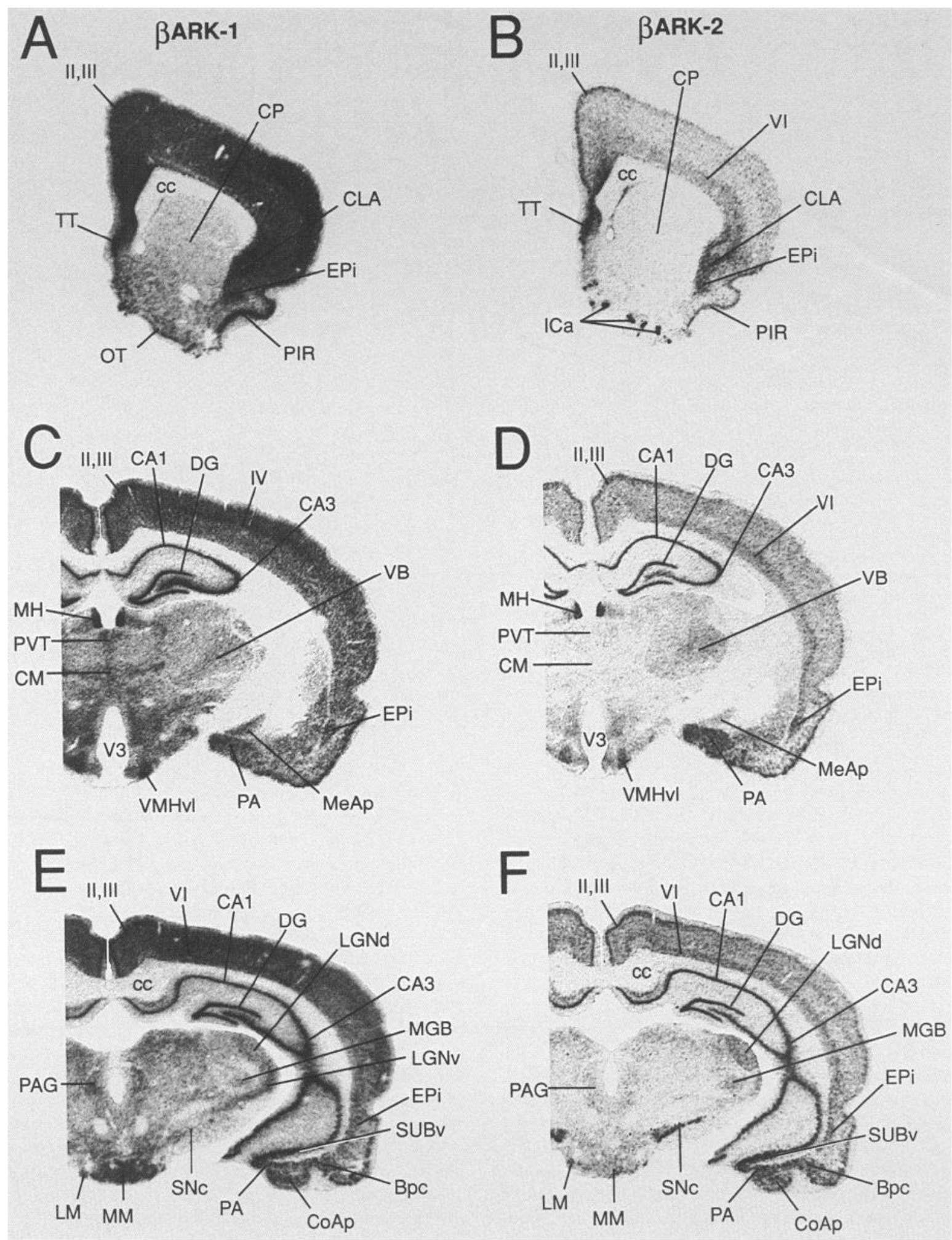

Figure 3. Comparison of $\beta$ ARK1 and $\beta$ ARK2 mRNA distributions in rat brain by in situ hybridization histochemistry: a series of film autoradiographic images ( $8 \mathrm{~d}$ exposure) that show the overall distribution of $\beta$ ARK1 $(A, C, E)$ and $\beta$ ARK2 $(B, D, F)$ mRNA expression in coronal sections of the rat forebrain. Abbreviations ( $n$, nucleus): $B p c$, basal n (amygdala) parvocellular part; $C A 1$, $C A 3$, fields of Ammon's Horn; $c c$, corpus callosum; $C L A$, claustrum; $C M$, central median n (thalamus); $C o A p$, cortical n (amygdala) posterior part; $C P$, caudate putamen; $D G$, dentate gyrus; $E P i$, endopiriform $\mathrm{n} ; I C a$, islands of Calleja; $I I, I I I, I V$ and $V I$, layers of isocortex; $L G N d$, lateral geniculate body (dorsal part); $L G N v$, lateral geniculate body (ventral part); $L M$, lateral mammillary n; $M e A p$, medial n (amygdala) posterior part; $M G B$, medial geniculate body; $M H$, medial habenula; $M M$, medial mammillary n; $O T$, olfactory tubercle; $P A$, posterior n (amygdala; a.k.a. amygdalohippocampal zone); $P A G$, periaqueductal gray; $P I R$, piriform cortex; $P V T$, paraventricular n (thalamus); $S N c$, substantia nigra (compact part); $S U B v$, subiculum (ventral part); $T T$, taenia tecta; $V 3$, third ventricle; $V B$, ventral basal complex; $V M H v l$, ventromedial n (hypothalamus) ventrolateral part. 
Figure 4. Immunoblots showing antibody specificity and $\beta A R K 1$ and $\beta A R K 2$ protein distributions in rat brain regions. The specificities of purified antibodies against either $\beta A R K 1$ (anti$\beta A R K 1$, top panels) or $\beta$ ARK2 (anti$\beta A R K 2$, bottom panels) were demonstrated by Western blot analyses of extracts from COS-7 cells expressing $\beta$ ARK cDNAs (left panels) and of extracts from dissected brain regions (right panels). $\beta$ ARK 1 and $\beta$ ARK 2 expressed in COS-7 cells migrated on SDS-polyacrylamide gels with different mobilities. Proteins detected in extracts from various dissected brain regions displayed mobilities similar to the expressed cDNA products (see arrows). Cell extracts $(20 \mu \mathrm{g}$ of protein per lane) and tissue extracts $(150 \mu \mathrm{g}$ of protein per lane) were size fractionated on $10 \%$ SDS-polyacrylamide gels, transferred to nitrocellulose, probed with anti$\beta A R K 1$ or anti- $\beta$ ARK2 antibody, and visualized with an alkaline phosphatase-conjugated secondary antibody. The positions of molecular weight standards are indicated (kilodaltons).

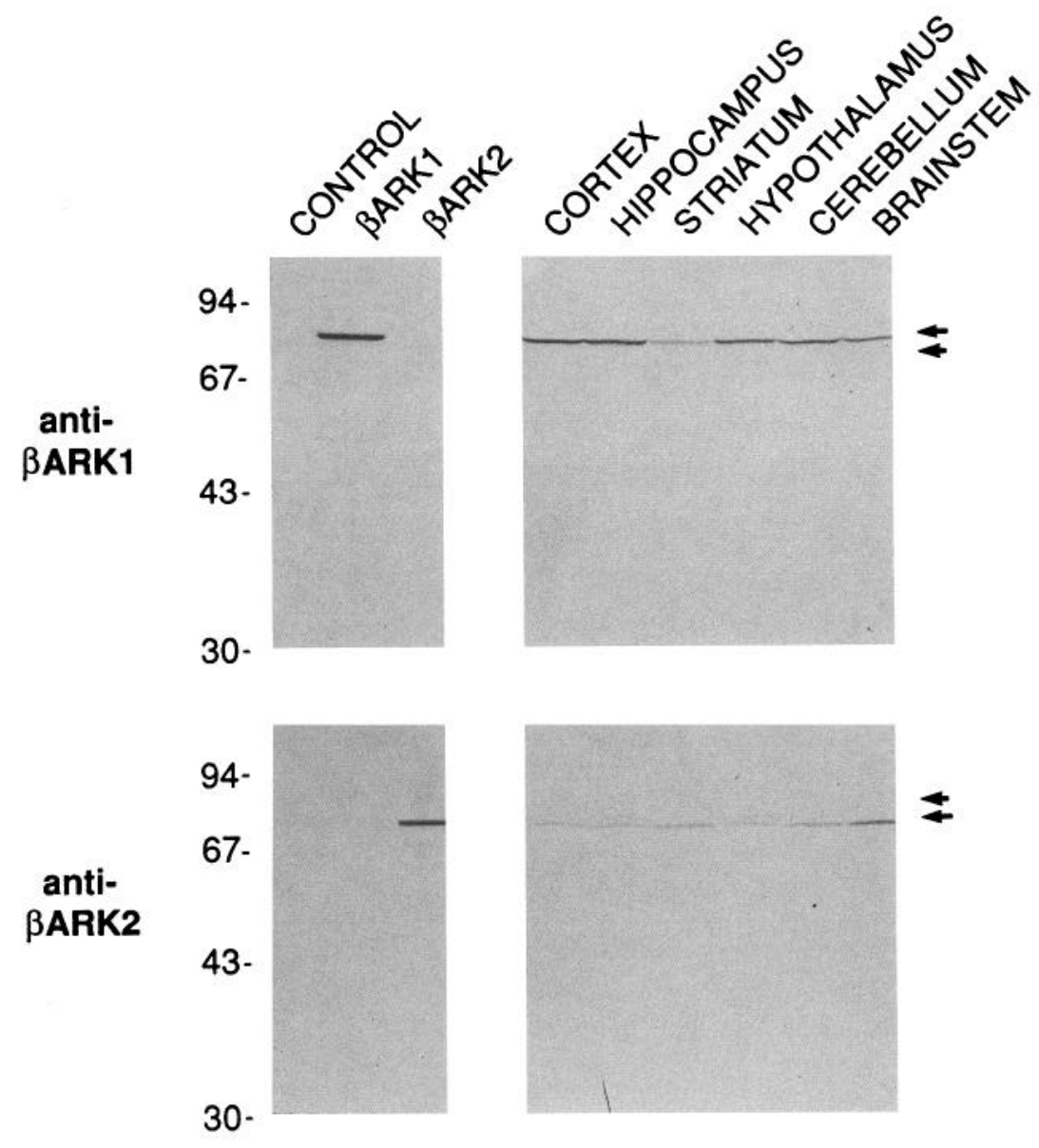

with the results obtained by in situ hybridization, $\beta$ ARK1 was expressed somewhat uniformly throughout these brain subdivisions, with lower levels in dissected striatum (largely caudate putamen). $\beta$ ARK2 protein was more difficult to visualize in these immunoblotting experiments, perhaps reflecting its overall lower abundance. The $\beta$ ARK 2 protein distribution was somewhat different than that of $\beta \mathrm{ARK} 1$, with higher relative levels in the brainstem and significant immunoreactive $\beta$ ARK 2 protein in the striatum.

\section{Regional distribution of $\beta A R K 1$ and $\beta A R K 2$ immunoreactivity in brain}

Immunohistochemical mapping of $\beta$ ARK 1 and $\beta$ ARK 2 immunoreactivity was performed throughout the rat brain using the anti- $\beta$ ARK1 and anti- $\beta$ ARK 2 antibodies. Sagittal sections illustrate the overall staining patterns for $\beta \mathrm{ARK} 1$ and $\beta \mathrm{ARK} 2$, and a representative control experiment in which antibody was preabsorbed with antigen supports the specificity of this staining (Fig. 5). The distributions of $\beta$ ARK immunoreactivities in coronal sections shown in Figure 6 parallel the regional distributions of $\beta$ ARK mRNAs obtained by in situ hybridization (Fig. 3). In this regard, the sensitivity of immunohistochemistry was apparently less than that of hybridization histochemistry. This difference was particularly significant for the localization of $\beta$ ARK 2 immunoreactivity. The correlation between the regional distributions of $\beta A R K$ isozyme mRNAs and $\beta A R K$ immunoreactivities argues for the specificity of these antibodies for immunohistochemistry.

$\beta \mathrm{ARK} 1$ and $\beta \mathrm{ARK} 2$ immunoreactivity was found distributed within neurons throughout the brain (Figs. 5, 6). In cerebral cortex, the $\beta$ ARK1 immunoreactivity was visualized in layers II and III as well as layers V and VI, whereas the distribution of $\beta$ ARK 2 immunoreactivity was less distinctly laminar. $\beta$ ARK1 and $\beta$ ARK 2 immunoreactivity was found in all subdivisions of the hippocampal formation, but $\beta$ ARK 1 staining was most intense in CA3-CA4 while $\beta$ ARK 2 was more evenly distributed. Labeling of many thalamic and hypothalamic structures was noted, with greater intensity for $\beta$ ARK1 staining than for $\beta$ ARK2 staining. Consistent with the presence of $\beta$ ARK1 and $\beta$ ARK2 within the striatum as determined by immunoblotting, labeling of striatal neuron cell bodies and of the neuropil was detected with both antibodies. Very strong labeling of the molecular layer in the cerebellum was seen with the $\beta$ ARK 1 antibody. $\beta$ ARK1 was most abundant in Purkinje cells, but moderate levels of $\beta \mathrm{ARK} 2$ were also found, and $\beta \mathrm{ARK} 2$ predominates in the granule cell layer. Although the $\beta$ ARK 2 antibody provided strong cellular staining in the substantia nigra and other structures, $\beta$ ARK2 immunoreactivity was often presented as diffuse labeling over cells. In contrast to the dense $\beta$ ARK 2 labeling in presumptive dopaminergic neurons in the substantia nigra, the neurons of the locus coeruleus displayed intense $\beta$ ARK 1 immunoreactivity and the dorsal raphe exhibited cellular staining for both $\beta$ ARK1 and $\beta$ ARK2.

\section{$\beta A R K 1$ and $\beta A R K 2$ are abundant at the synapse}

Analyses of $1 \mu \mathrm{m}$ sections using high-resolution light microscopy indicated that $\beta \mathrm{ARK}$ immunoreactivities are clearly present within neuronal cell bodies and fine processes within the neu- 
A

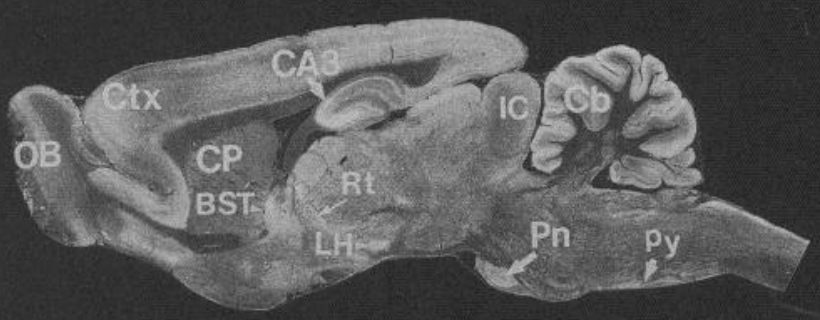

\section{BARK-1}

-

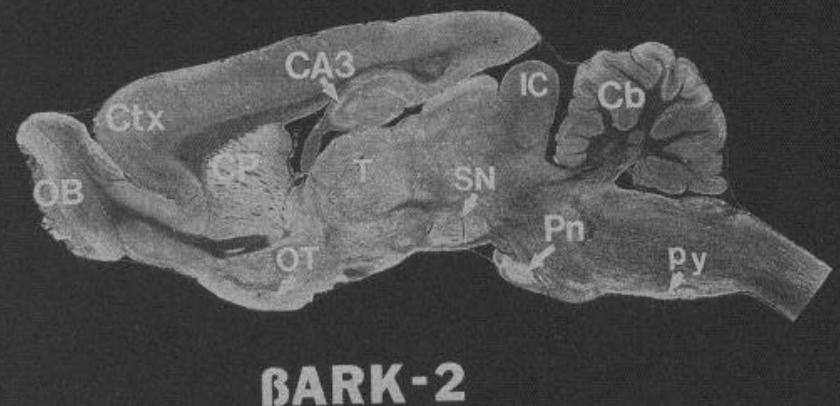

Figure 5. Comparative distributions of $\beta$ ARK 1 and $\beta$ ARK 2 immunoreactivities in rat brain: dark-field photomicrographs of serial sagittal sections of the rat brain immunostained with either the anti- $\beta$ ARK 1 antibody $(A)$ or the anti- $\beta$ ARK2 antibody $(B)$. A representative blocking experiment $(C)$ in which the anti- $\beta$ ARK 1 antibody was preabsorbed with $100 \mu \mathrm{g}$ of antigen (purified $\beta$ ARK 1 fusion protein) illustrates the specificity of immunostaining. Sections in $A$ and $C$ were processed and photographed under identical conditions. Similar results were obtained with the anti- $\beta$ ARK2 antibody preabsorbed with antigen (data not shown). Abbreviations: $B S T$, bed nucleus of stria terminalis; $C P$, caudate putamen; $C b$, cerebellum; $C t x$, cortex; $C A 3$, field of Ammon's Horn; $I C$, inferior colliculus; $L H$, lateral anterior hypothalamic nucleus; $C A 1-C A 3$, fields of Ammon's Horn; $O B$, olfactory bulb; $O T$, olfactory tubercle; $P n$, pontine nuclei; $P y$, pyramidal tract; $R t$, reticular thalamic nuclei; $S N$, substantia nigra; $T$, thalamus. 


\section{BARK-1}

A

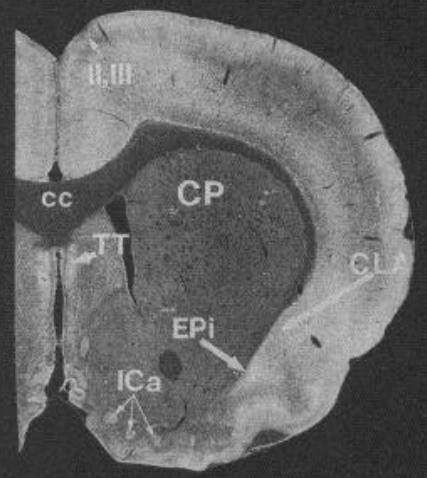

C

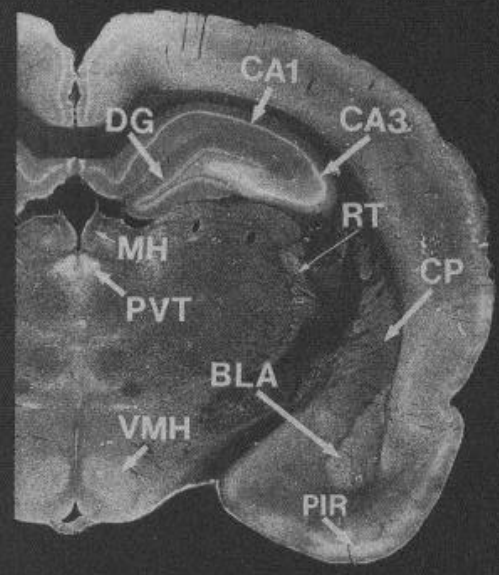

E

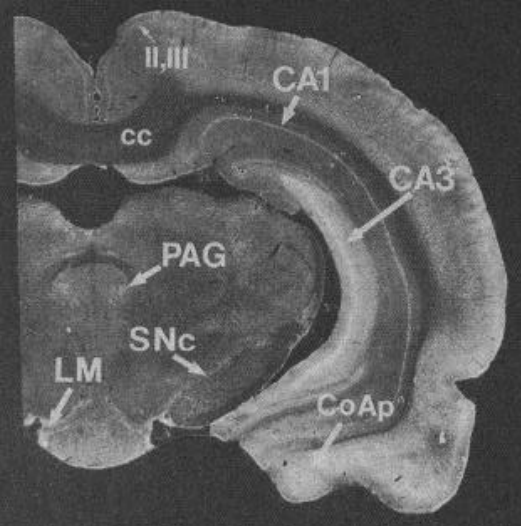

BA RK - 2

B

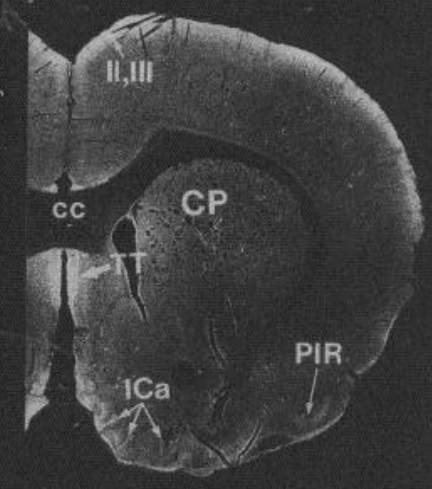

D

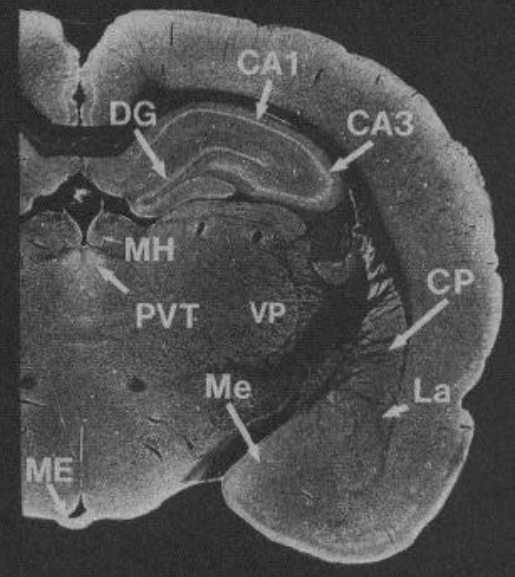

F

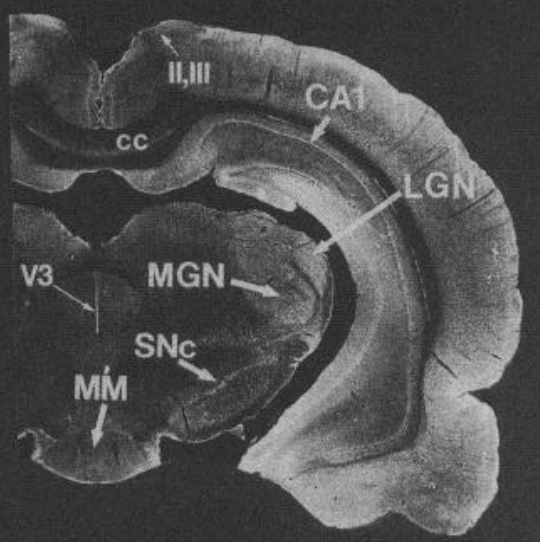


ropil (Fig. $7 A, B$ ). Immunoreactive neurons showed diffuse cytoplasmic labeling, and the nuclei of immunoreactive cells did not contain immunoreaction product. Within the neuropil of the brain regions analyzed in plastic sections (e.g., cortex, hippocampus, cerebellum, and striatum), $\beta$ ARK 1 and $\beta$ ARK 2 immunoreactivities were within spherical or punctate structures. Most of these immunoreactive structures correspond to dendritic shafts, dendritic spines, or presynaptic axon terminals, as confirmed by immunocytochemical-ultrastructural analyses.

Electron microscopic analyses of striatum and other regions were performed using the $\beta \mathrm{ARK} 1$ and $\beta \mathrm{ARK} 2$ antibodies, and ultrastructurally, $\beta$ ARK immunoreactivities were visualized both postsynaptically and presynaptically (Fig. 7). Immunoreactivity localized with the $\beta$ ARKI antibody was enriched in the cytoplasm of dendritic shafts and dendritic spines and associated with postsynaptic densities, as well as in presynaptic axon terminals. $\beta$ ARK1 immunoreactivity in neuronal cell bodies frequently showed enrichment on or near the plasma membrane. In contrast, the distribution of $\beta$ ARK 2 -specific immunoreactivity in the striatum was somewhat more restricted than the $\beta$ ARK 1 distribution. Striatal $\beta$ ARK 2 immunoreactivity was also associated with postsynaptic densities and on presynaptic elements. Other regions of the brain were also examined, and preliminary results suggest that there may be some regional variations in the relative proportions of postsynaptic versus presynaptic $\beta$ ARK, but that both postsynaptic and presynaptic localizations are common.

\section{Discussion}

Receptor desensitization by $\beta \mathrm{ARK}$ is a homologous mechanism by which transmembrane signal transduction may be attenuated. This desensitization pathway, delineated for the $\beta_{2} \mathrm{AR}$, provides a conceptual framework for $\beta$ ARK-mediated desensitization of other G-protein-coupled receptors. The $\beta_{2} \mathrm{AR}$ is rapidly phosphorylated and desensitized by $\beta$ ARK at high agonist concentrations (Hausdorff et al., 1990; Roth et al., 1991). $\beta$ ARK-mediated desensitization is sensitive to ligand concentrations because of the requirement for agonist-occupation of the receptor. Phosphorylation of the $\beta_{2} \mathrm{AR}$ by $\beta$ ARK promotes the binding of $\beta$-arrestin, a cofactor that blocks functional receptor coupling with the signal-transducing G-protein (Lohse et al., 1990). Receptor function is thereby impaired until the activity of a protein phosphatase allows resensitization (Sibley et al., 1986).

Since $\beta$ ARK isozymes initiate this regulatory pathway, considerable attention has focused on their characterization. Extensive screening of brain CDNA libraries has led to the cloning of two $\beta \mathrm{ARK}$ isozymes, $\beta \mathrm{ARK} 1$ and $\beta \mathrm{ARK} 2$. Whether additional G-protein-coupled receptor kinases are expressed in brain is unclear. The rat $\beta A R K 1$ and $\beta A R K 2$ proteins have striking structural similarities, with over $80 \%$ amino acid sequence identity (Fig. 1). Both isozymes are active in functional assays for phosphorylation of the $\beta_{2} \mathrm{AR}$, although $\beta \mathrm{ARK} 1$ is more active than $\beta$ ARK2 (Benovic et al., 1991; Fig. 2). These results suggest similar but distinct substrate specificities for the $\beta \mathrm{ARK}$ isozymes, and biochemical analyses of $\beta A R K 1$ and $\beta$ ARK 2 activities on other G-protein-coupled receptors will be an important step toward understanding their respective physiological functions. In this study, we have assessed the potential biological functions of $\beta \mathrm{ARK} 1$ and $\beta \mathrm{ARK} 2$ by examining their respective distributions in brain. Brain was chosen because of its wellcharacterized complexity of neurotransmitter systems, but also because the $\beta$ ARK isozymes appear to have a special significance in nervous tissue. We show that both $\beta A R K$ isozymes have similar patterns of expression in neurons distributed throughout the brain, and that $\beta$ ARK 1 and $\beta$ ARK 2 are abundant at the synapse.

The regional distributions of the $\beta$ ARK isozyme mRNAs and proteins were examined using in situ hybridization histochemistry (Fig. 3) and immunohistochemistry (Figs. 5, 6). The $\beta$ ARK1 and $\beta A R K 2$ distributions were very extensive, but not ubiquitous, with detectable expression throughout each major subdivision of the brain. Overall, $\beta$ ARK 1 levels of $\mathrm{mRNA}$ and protein were significantly higher than those of $\beta A R K 2$, but the relative levels of isozyme expression were regionally variable. Within a few brain structures, such as the substantia nigra, $\beta$ ARK2 gene products appeared more abundant. Rather than exhibiting distinct regional distributions, $\beta$ ARK1 and $\beta$ ARK2 are to a great extent codistributed, suggesting that $\beta A R K 1$ and $\beta A R K 2$ are localized within common neurotransmitter pathways.

Although $\beta$ ARK isozymes have been characterized in vitro on the basis of their activities toward the $\beta_{2} A R$, other G-proteincoupled receptors have also been demonstrated as $\beta$ ARK substrates (Benovic et al., 1987c; Kwatra et al., 1989). The regional distributions of $\beta$ ARK 1 and $\beta$ ARK 2 reported here also suggest a more general substrate preference. $\beta_{2} \mathrm{ARs}$ (and the $\beta_{1} \mathrm{AR}$ ) have been mapped by quantitative autoradiography in the rat brain (Rainbow et al., 1984). The $\beta_{2}$ AR binding sites in the molecular layer of the cerebellum coincide with $\beta A R K 1$ immunoreactivity is this region. However, the high density of $\beta_{2} A R$ reported in the caudate putamen is not paralleled by a high level of either $\beta A R K 1$ or $\beta A R K 2$. The patterns of $\beta$ ARK isozyme immunoreactivities do not present a striking correlation with any known receptor system, although the association of $\beta \mathrm{ARK} 2$ with dopaminergic pathways and some regions that contain dopamine receptors is intriguing. We find that the extensive distributions of $\beta$ ARK1 and $\beta$ ARK2 support the hypothesis that these enzymes have a general function in the desensitization of many $\mathrm{G}$-protein-coupled receptor systems.

$\beta A R K$ isozyme mRNAs and proteins were found to be most abundant in neurons. In some brain regions, the density of labeled neurons was such that coexpression of $\beta \Lambda \mathrm{RK} 1$ and $\beta A R K 2$ within individual cells seems likely. This may indicate

\section{$\longleftarrow$}

Figure 6. $\beta$ ARK1 and $\beta$ ARK2 immunoreactivity in coronal sections of rat brain. These dark-field photomicrographs illustrate the similarity of the distributions of $\beta$ ARK1 $(A, C, E)$ and $\beta$ ARK2 $(B, D, F)$ immunoreactivities to the corresponding mRNA distributions determined by in situ hybridization. The sections shown contain structures similar to those presented in Figure 3 . Abbreviations: $B L A$, basolateral amygdaloid nucleus; $C A 1, C A 3$, fields of Ammon's Horn; $c c$, corpus callosum; $C L A$, claustrum; $C o A P$, posterior cortical amygdaloid nucleus; $C P$, caudate putamen; $D G$, dentate gyrus; $E P i$, endopiriform nucleus; $I C a$, islands of Calleja; $I I, I I I$, lamina of cortex; $L a$, lateral amygdaloid nucleus; $L G N$, lateral geniculate nucleus; $L M$, lateral mammillary nucleus; $M e$, medial posterior amygdaloid nucleus; $M E$, median eminence; $M G N$, medial geniculate nuclcus; $M H$, mcdial habenula; $M M$, medial mammillary nuclcus; $P A G$, periaqueductal gray; $P I R$, piriform cortex; $P V T$, periventricular thalamic nucleus; $R T$, reticular thalamic nucleus; $S N C$, substantia nigra pars compacta; $T T$, taenia tecta; $V 3$, third ventricle; $V M H$, ventromedial hypothalamic nucleus; $V P$, ventral posterior thalamic nucleus. 

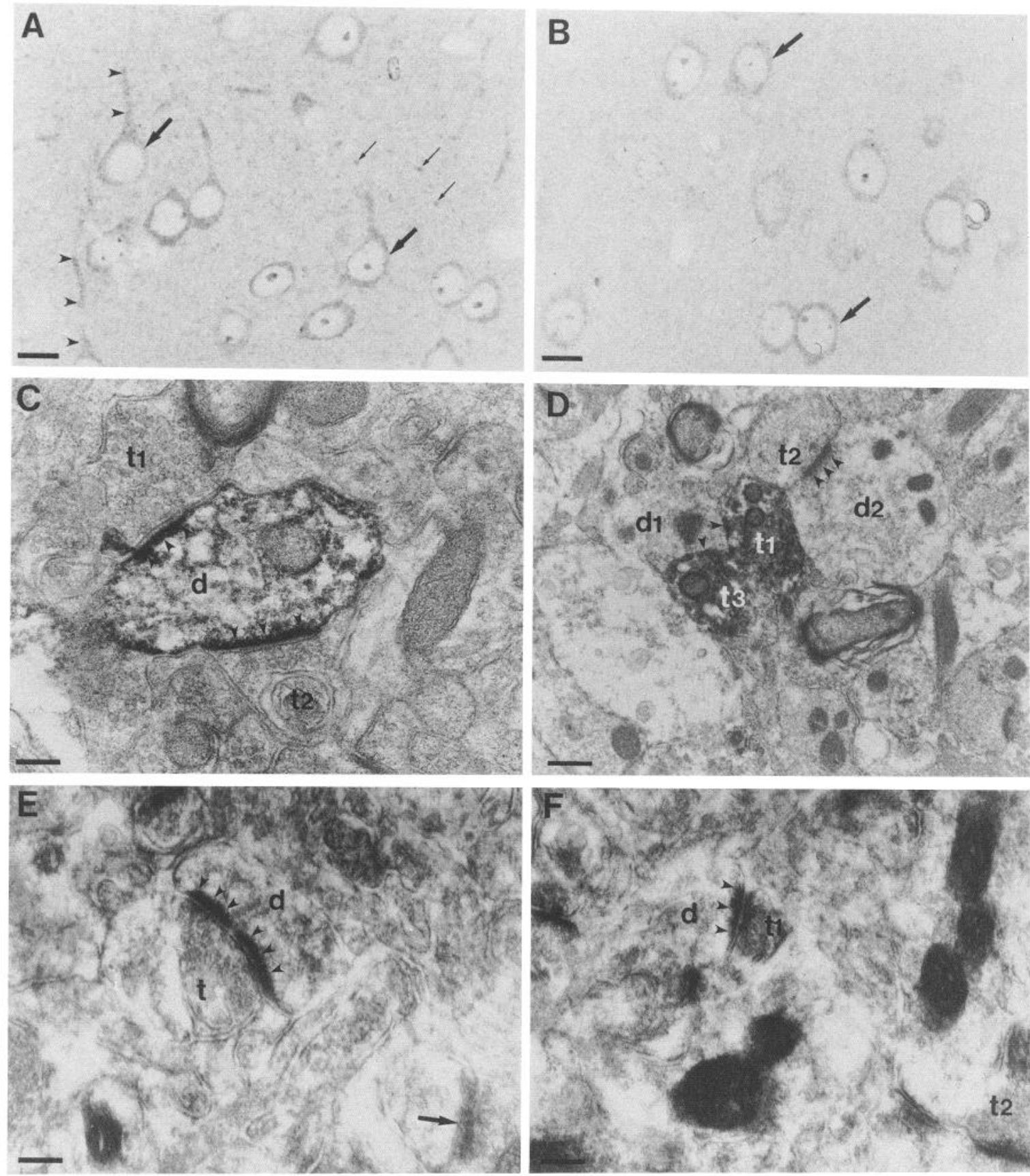

Figure 7. High-resolution light and electron microscopic localization of $\beta$ ARK immunoreactivity in rat brain. $A$, In $1 \mu \mathrm{m}$ sections of neocortex, $\beta A R K 1$ immunoreactivity is localized within the cell bodies of neurons (large arrows) and in dendrites (arrowheads). The neuropil contains spherical and punctate structures immunoreactive for $\beta$ ARK1 (small arrows). $B$, The distribution of $\beta$ ARK2 immunoreactivity in plastic sections of neocortex was different from the $\beta$ ARK1 distribution. $\beta$ ARK2 immunoreactivity is localized in neuronal perikarya (arrows), but distal dendrites are not immunoreactive and there is less large, punctate immunoreactivity within the neuropil. Some diffuse $\beta$ ARK 2 immunoreactivity is visualized within the neuropil. $C, \beta$ ARK1 immunoreactivity was enriched in dendritic shafts $(d)$. This immunoreactive dendrite is postsynaptic to unlabeled terminals $(t 1$ and $t 2$ ) that form asymmetrical synapses (arrowheads). $D, \beta$ ARK1 immunoreactivity is visualized presynaptically as well. $\beta$ ARK1-immunoreactive axon terminals $(t 1$ and $t 3)$ are beginning to form synaptic junctions (single arrowheads) with a dendrite $(d I)$ in this plane of section. In terminals $t 1$ and $t 3, \beta$ ARK 1 immunoreactivity is associated with vesicles. Nonimmunoreactive terminal $t 2$ forms synaptic contacts (triple arrowheads) with dendrite $d 2$. E. In $\beta$ ARK 2 preparations, some postsynaptic densities (arrowheads) formed here by the junction of terminal ( $t$ ) with dendrite $(d)$ are more electron dense that other postsynaptic densities (arrow), suggesting the localization of $\beta$ ARK 2 within postsynaptic densities. $F$, Axon terminals $(t I)$ immunoreactive for $\beta$ ARK 2 are also encountered. $\beta$ ARK 2 -immunoreactive postsynaptic density (arrowheads) is at a dendrite (d). Terminal $t 2$ is an unlabeled terminal. Scale bars: $A$ and $B, 10 \mu \mathrm{m} ; C, 0.2 \mu \mathrm{m} ; D, 0.4 \mu \mathrm{m} ; E, 0.25 \mu \mathrm{m} ; F, 0.33 \mu \mathrm{m}$.

that the $\beta$ ARK isozymes have separate but complementary functions within neurons. Although some differences in cellular staining for $\beta$ ARK1 and $\beta$ ARK2 were observed (Fig. 7), these differences may be attributed to difficulties in detecting very low levels of $\beta$ ARK2 protein. Both $\beta$ ARK1 and $\beta$ ARK 2 immunoreactivities were found within the cell bodies of neurons, as well as within structures that correspond to dendritic shafts, dendritic spines, and presynaptic axon terminals. 
Ultrastructurally, $\beta \mathrm{ARK} 1$ and $\beta \mathrm{ARK} 2$ immunoreactivities were present both in association with postsynaptic densities and, presynaptically, within axon terminals (Fig. 7). Postsynaptic and presynaptic localizations of $\beta$ ARK 1 and $\beta$ ARK 2 are both found in various brain regions, with postsynaptic distributions generally predominating. Subcellular distributions within the striatum are illustrated to emphasize that the $\beta$ ARK isozymes may be presynaptic as well as postsynaptic. Whereas $\beta$ ARK isozyme mRNAs were found at low levels within the striatum (Fig. 3), immunoblotting (Fig. 4) and immunohistochemistry (Figs. 5, 6 ) indicated that moderate levels of $\beta A R K 1$, and particularly $\beta A R K 2$, were present within the striatum. One possible explanation is that diffuse immunoreactivity within the neuropil of the striatum may correspond to terminal immunoreactivity originating within the substantia nigra, cortex, or thalamus. The observation that presynaptic immunoreactivity is present in the striatum supports this notion.

Although the desensitization of synaptic responses is a common phenomenon, its physiological significance is poorly understood. Desensitization may control the duration and/or strength of synaptic transmission under normal conditions, and perhaps serve a protective role under conditions of excessive stimulation. The tools and observations reported here provide a foundation for future investigations of the potentially diverse functions of these $\mathrm{G}$-protein-coupled receptor kinases.

\section{References}

Andersson S, Davis DL, Dahlback H, Jornvall H, Russel DW (1989) Cloning, structure, and expression of the mitochondrial cytochrome P-450 sterol 26-hydroxylase, a bile acid biosynthetic enzyme. J Biol Chem 264:8222-8229.

Benovic JL, Shorr RGL, Caron MG, Lefkowitz RJ (1984) The mammalian $\beta_{2}$-adrenergic receptor: purification and characterization. Biochemistry $23: 4510-4518$.

Benovic JL, Mayor F Jr, Somers RL, Caron MG, Lefkowitz RJ (1986) Light-dependent phosphorylation of rhodopsin by $\beta$-adrenergic receptor kinase. J Biol Chem 262:9026-9032.

Benovic JL, Mayor F Jr, Staniszewski C, Lefkowitz RJ, Caron MG (1987a) Purification and characterization of the $\beta$-adrenergic receptor kinase. J Biol Chem 262:9026-9032.

Benovic JL, Kuhn H, Weyland I, Codina J, Caron MG, Lefkowitz RJ (1987b) Functional desensitization of the isolated $\beta$-adrenergic receptor by the $\beta$-adrenergic receptor kinase: potential role of an analog of the retinal protein arrestin (48-kDa protein). Proc Natl Acad Sci USA 84:8879-8882.

Benovic JL, Regan JW, Matsui H, Mayor F Jr, Cotecchia S, LeebLundberg LMF, Caron MG, Lefkowitz RJ (1987c) Agonist-dependent phosphorylation of the $\alpha_{2}$-adrenergic receptor by the $\beta$-adrenergic receptor kinase. J Biol Chem 262:17251-17253.

Benovic JL, Bouvier M, Caron MG, Lefkowitz RJ (1988) Regulation of adenylyl cyclase-coupled $\beta$-adrenergic receptors. Annu Rev Cell Biol 4:405-428.

Benovic JL, DeBlasi A, Stone WC, Caron MG, Lefkowitz RJ (1989) $\beta$-Adrenergic receptor kinase: primary structure delineates a multigene family. Science 246:235-240.

Benovic JL, Onorato JJ, Arriza JL, Stone WC, Lohse M, Jenkins NA, Gilbert DJ, Copeland NG, Caron MG, Lefkowitz RJ (1991) Cloning, expression, and chromosomal localization of $\beta$-adrenergic receptor kinase 2. J Biol Chem 266:14939-14946.
Bradford MM (1976) A rapid and sensitive method for the quantitation of microgram quantities of protein utilizing the principle of protein-dye binding. Anal Biochem 72:248-254.

Cerione RA, Strulovici B, Benovic JL, Lefkowitz RJ, Caron MG (1983) Pure $\beta$-adrenergic receptor: the single polypeptide confers catecholamine responsiveness to adenylate cyclase. Nature 306:562-566.

Greengard P, Jen J, Nairn AC, Stevens CF (1991) Enhancement of the glutamate response by cAMP-dependent protein kinase in hippocampal neurons. Science 235:1135-1138.

Hausdorff WP, Bouvier M, O'Dowd BF, Irons GP, Caron MG, Lefkowitz RJ (1989) Phosphorylation sites on two domains of the $\beta_{2}$ adrencrgic receptor are involved in distinct pathways of receptor desensitization. J Biol Chem 264:12657-12665.

Hausdorff WP, Caron MG, Lefkowitz RJ (1990) Turning off the signal: desensitization of $\beta$-adrenergic receptor function. FASEB J 4:28812889.

Huganir RL, Greengard P (1990) Regulation of neurotransmitter receptor desensitization by protein phosphorylation. Neuron 5:555567.

Klein WL, Sullivan J, Skorupa A, Aguilar JS (1989) Plasticity of neuronal receptors. FASEB J 3:2132-2140.

Kwatra MM, Benovic JL, Caron MG, Lefkowitz RJ, Hosey MM (1989) Phosphorylation of chick heart muscarinic cholinergic receptors by the $\beta$-adrenergic receptor kinase. Biochemistry 28:4543-4547.

Laemmli UK (1970) Cleavage of structural proteins during the assembly of the head of bacteriophage T4. Nature 227:680-685.

Lewis ME, Shermen TG, Watson SJ (1985) In situ hybridization histochemistry with synthetic oligonucleotides: strategies and methods. Peptides 6[Suppl 2]:75-87.

Lohse MJ, Benovic JL, Codina J, Caron MG, Lefkowitz RJ (1990) $\beta$ Arrestin: a protein that regulates $\beta$-adrenergic receptor function. Science 248:1547-1550.

Lopeta MA, Cleveland DW, Sollner-Webb B (1984) High level transient expression of a chloramphenicol acetyl transferase gene by DEAEdextran mediated DNA transfection coupled with a dimethyl sulfoxide or glycerol shock treatment. Nucleic Acids Res 12:5707-5717.

Rainbow TC, Parsons B, Wolfe BB (1984) Quantitative autoradiography of $\beta 1$ - and $\beta 2$-adrenergic receptors in rat brain. Proc Natl Acad Sci USA 81:1585-1589.

Roth NS, Campbell PT, Caron MG, Lefkowitz RJ, Lohse MJ (1991) Comparative rates of desensitization of $\beta$-adrenergic receptors by the $\beta$-adrenergic receptor kinase and the cyclic AMP-dependent protein kinase. Proc Natl Acad Sci USA 88:6201-6204.

Sanger F, Nicklen S, Coulson AR (1977) DNA sequencing with chain terminating inhibitors. Proc Natl Acad Sci USA 74:5463-5467.

Sibley DR, Strasser RH, Benovic JL, Daniel K, Lefkowitz RJ (1986) Phosphorylation/dephosphorylation of the $\beta$-adrenergic receptor regulates its functional coupling to adenylate cyclase and subcellular distribution. Proc Natl Acad Sci USA 83:9408-9412.

Sibley DR, Benovic JL, Caron MG, Lefkowitz RJ (1987) Regulation of transmembrane signaling by receptor phosphorylation. Cell 48 : 913-922.

Simerly RB, Young BJ (1991) Regulation of estrogen receptor messenger ribonucleic acid in rat hypothalamus by sex steroid hormones. Mol Endocrinol 5:424-432.

Simerly RB, Chang C, Muramatsu M, Swanson LW (1990) Distribution of androgen and estrogen receptor mRNA-containing cells in the rat brain: an in situ hybridization study. J Comp Neurol 294:7695.

Smith DB, Johnson KS (1988) Single-step purification of polypeptides expressed in Escherichia coli as fusions with glutathione S-transferase. Gene 67:31-40.

Wang L-Y, Salter MW, MacDonald JF (1991) Regulation of kainate receptors by cAMP-dependent protein kinase and phosphatases. Science 253:1132-1135. 